\title{
Protocol
}

\section{Splinted Ligation Method to Detect Small RNAs}

\author{
Timothy W. Nilsen
}

In any cell, the number of RNA species is remarkably complex. The sizes of RNAs can vary from 20 nucleotides to several kilobases, and abundances can vary from a few to hundreds of thousands of molecules per cell. It is of obvious interest to determine the abundance and integrity of specific RNA species within these complex mixtures. This protocol describes the splinted ligation method to detect small RNAs. It relies on the ability of T4 DNA ligase to covalently join the terminal 3'-hydroxyl group of an RNA molecule to the labeled 5'-phosphate group of a DNA chain in the presence of a DNA "splint" or "bridge" oligonucleotide that is complementary to both. After ligation, the labeled small RNA, lengthened by the covalent addition of the ${ }^{32} \mathrm{P}$-labeled oligonucleotide probe, is visualized by denaturing gel electrophoresis and phosphorimaging. This approach is recommended for the routine detection and quantification of specific small RNAs (e.g., microRNAs [miRNAs] and piwi-associated RNAs [piRNAs]).

It is essential that you consult the appropriate Material Safety Data Sheets and your institution's Environmental Health and Safety Office for proper handling of equipment and hazardous materials used in this protocol.

RECIPES: Please see the end of this article for recipes indicated by $<\mathrm{R}>$. Additional recipes can be found online at http://cshprotocols.cshlp.org/site/recipes.

\section{Reagents}

Alkaline phosphatase (10 units/ $\mu \mathrm{L})$

Annealing buffer $(10 \times)<\mathrm{R}>$

Bridge $(7.5 \mathrm{ng} / \mu \mathrm{L})$ and ligation $(100 \mathrm{ng} / \mu \mathrm{L})$ oligonucleotides

Design the bridge oligonucleotide so that $\sim 20$ nucleotides of its $3^{\prime}$ end are perfectly complementary to the target RNA and its 5' end is perfectly complementary to the 14-nucleotide ligation oligonucleotide (see Fig. 1). The ligation oligonucleotide (and its complement) can be composed of arbitrary sequence, but the sequence should not impart significant secondary structure to the bridge oligonucleotide as a whole. For best results, include a nonligatable end (e.g., dideoxy or carbon spacer) at both the $3^{\prime}$ end of the ligation oligonucleotide and the $3^{\prime}$ end of the bridge oligonucleotide. If the sequence in the ligation oligonucleotide and its complement in the bridge oligonucleotide are always the same, the same ligation oligonucleotide can always be used.

Denaturing acrylamide gel (6\%)

Formamide loading dye

$\left[\gamma^{3}{ }^{32} \mathrm{P}\right]$ ATP $(6000 \mathrm{Ci} / \mathrm{mmol}, 150 \mu \mathrm{Ci} / \mu \mathrm{L})$

Adapted from RNA: A Laboratory Manual, by Donald C. Rio, Manuel Ares Jr, Gregory J. Hannon, and Timothy W. Nilsen. CSHL Press, Cold Spring Harbor, NY, USA, 2011.

(C) 2013 Cold Spring Harbor Laboratory Press

Cite this article as Cold Spring Harb Protoc; 2013; doi:10.1101/pdb.prot072611 


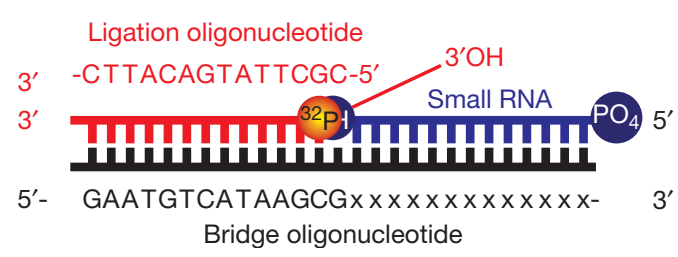

Kinase buffer $(10 \times)<\mathrm{R}>$

Ligation buffer $(2 \times)<\mathrm{R}>$

Alternative ligase buffers are available commercially. If choosing these buffers, adjust concentrations accordingly (e.g., $2.5 \mu \mathrm{L}$ of $5 \times$ buffer per $12.5 \mu \mathrm{L}$ of ligation reaction).

OptiKinase (10 units/ $\mu \mathrm{L} ;$ Affymetrix/USB Products)

T4 DNA ligase (10 units/ $\mu \mathrm{L}$ )

Total RNA $(1 \mu \mathrm{g} / \mu \mathrm{L})$

Alternatively, use a sample enriched for small (<30-nucleotide) RNAs.

Equipment

Autoradiography or phosphorimaging equipment

Gel drier

Heat block $\left(95^{\circ} \mathrm{C}\right)$

Incubator or water bath $\left(37^{\circ} \mathrm{C}\right)$

Micro Bio-Spin 6 Column (Bio-Rad)

Microcentrifuge

Microcentrifuge tubes $(1.5 \mathrm{~mL})$

Polymerase chain reaction (PCR) tubes

Power supply and electrophoresis apparatus for denaturing acrylamide gels

Thermal cycler (Redrawn, with permission, from Maroney et al. 2008 [C Macmillan].)
FIGURE 1. Bridge oligonucleotide sequence design.

1. Label the ligation oligonucleotide.

i. Assemble the following reaction in a $1.5-\mathrm{mL}$ microcentrifuge tube:

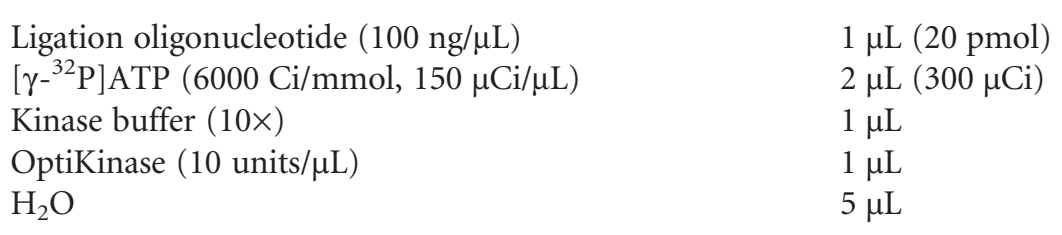

ii. Incubate the reaction for $20 \mathrm{~min}$ at $37^{\circ} \mathrm{C}$.

iii. Dilute with $50 \mu \mathrm{L}$ of $\mathrm{H}_{2} \mathrm{O}$ and run through a Micro Bio-Spin 6 Column.

iv. Phenol-extract and then ethanol-precipitate with glycogen (see Purification of RNA by SDS Solubilization and Phenol Extraction [Rio et al. 2010a] and Ethanol Precipitation of RNA and the Use of Carriers [Rio et al. 2010b]).

v. Resuspend the labeled ligation oligonucleotide in $75 \mu \mathrm{L}$ of $\mathrm{H}_{2} \mathrm{O}$. 
T.W. Nilsen

2. Prepare a mix containing the following:

Annealing buffer $(10 x)$

$5 \mu \mathrm{L}$

Labeled ligation oligonucleotide from Step 1.v

$5 \mu \mathrm{L}(1 \mathrm{pmol})$

Bridge oligonucleotide $(7.5 \mathrm{ng} / \mu \mathrm{L})$

$\mathrm{H}_{2} \mathrm{O}$

$1.5 \mu \mathrm{L}(1 \mathrm{pmol})$

$8.5 \mu \mathrm{L}$

This volume is enough for 9-10 reactions.

3. Add $2.0 \mu \mathrm{L}$ of the mix from Step 2 to $3 \mu \mathrm{L}$ of total RNA $(1 \mu \mathrm{g} / \mu \mathrm{L})$ in a PCR tube. Place the tube in a thermal cycler. Denature for $1 \mathrm{~min}$ at $95^{\circ} \mathrm{C}$ and then anneal for $2 \mathrm{~min}$ at $65^{\circ} \mathrm{C}$ and for $10 \mathrm{~min}$ at $37^{\circ} \mathrm{C}$.

If the RNA of interest (and bridge oligonucleotide) have secondary structure, the annealing conditions may need to be optimized.

4. While the annealing reaction is taking place, prepare the following ligation mix:

$\begin{array}{lr}\text { Ligation buffer }(2 \times) & 62 \mu \mathrm{L} \\ \text { T4 DNA ligase }(10 \text { units/ } \mu \mathrm{L}) & 2 \mu \mathrm{L} \\ \mathrm{H}_{2} \mathrm{O} & 11 \mu \mathrm{L}\end{array}$

This mix is sufficient for 10 reactions.

5. Add $7.5 \mu \mathrm{L}$ of ligation mix to the $5-\mu \mathrm{L}$ annealing reaction and mix well by pipetting up and down. Incubate for $1 \mathrm{~h}$ at room temperature.

6. Stop the reaction by adding $1 \mu \mathrm{L}$ of 10 units/ $\mu \mathrm{L}$ alkaline phosphatase and incubate for $15 \mathrm{~min}$ at $37^{\circ} \mathrm{C}$.

Samples can be stored for $2-4 \mathrm{wk}$ at $-20^{\circ} \mathrm{C}$.

7. Remove $2.5 \mu \mathrm{L}$ of the sample and add $5 \mu \mathrm{L}$ of formamide loading dye.

8. Denature for $2 \mathrm{~min}$ at $95^{\circ} \mathrm{C}$ and place on ice.

9. Load samples on a denaturing $6 \%$ acrylamide gel that has been prerun for at least $45 \mathrm{~min}$. After loading the samples, run the gel until the bromophenol blue dye has migrated $15 \mathrm{~cm}$ from the wells. Dry the gel and visualize the bands using autoradiography or phosphorimaging.

Small RNAs, lengthened by the addition of the labeled DNA oligonucleotide, should be detected as distinct bands (Fig. 2). See Troubleshooting.

Problem (Step 9): Aberrant bands are detected.

Solution: These bands may represent fragments of degraded DNA in the RNA sample. To solve this problem, do not use DNase-treated RNA samples. Try incubating the ligation reactions at $30^{\circ} \mathrm{C}$ instead of at room temperature.

Problem (Step 9): No bands are detected.

Solution: Consider the following:

- Excess bridge oligonucleotide may have been used. The ligation oligonucleotide must be present in an equimolar ratio to or in excess of the bridge oligonucleotide. If the bridge oligonucleotide is in excess, the RNA of interest and the ligation oligonucleotide may have annealed to separate molecules and thus did not ligate. Carefully quantitate the oligonucleotides.

- The oligonucleotides may not have been designed appropriately. Make sure that the $3^{\prime}$ end of the RNA of interest is known to be accurate. To exclude technical problems, run a control reaction with reagents and RNAs of known quality using a bridge oligonucleotide to a known abundant RNA. Check for secondary structure in the bridge oligonucleotide and if secondary structure is present, optimize the annealing conditions and/or increase the ligation temperature to $30^{\circ} \mathrm{C}$. 


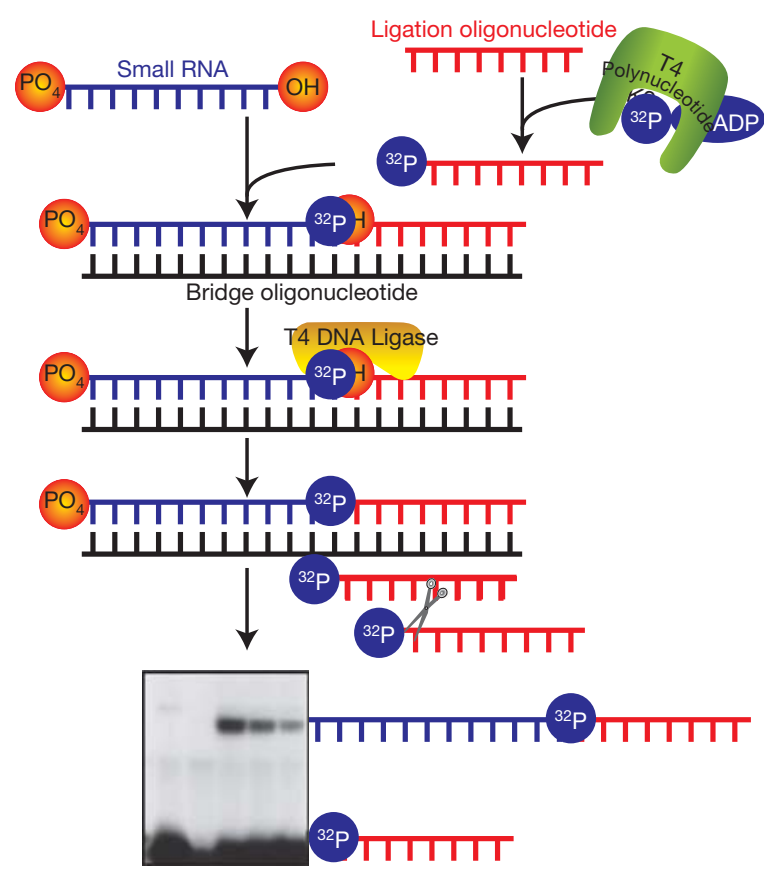

FIGURE 2. Schematic depiction of the splinted ligation method for detecting small RNAs The gel shows detection of a specific miRNA expressed in HeLa cells using three different amounts of input RNA. (Adapted, with permission, from Maroney et al. 2008 [@Macmillan].)

The discovery and subsequent explosion of interest in small noncoding RNAs such as miRNAs, piRNAs, and endogenous small interfering RNAs (siRNAs) have prompted the development of a variety of sensitive methods designed to detect and quantify the expression of these RNAs. At least 20 distinct methodologies of varying complexities and utilities have been described and each has its own advantages and disadvantages. Somewhat surprisingly, northern blotting remains the most reliable and popular method for detecting small RNAs, despite its relatively poor sensitivity.

Ligation-mediated detection is highly specific because DNA ligase will only join RNA and DNA molecules that are perfectly aligned on the bridge oligonucleotide (i.e., no gaps or mismatches at the junction). We have found that it is significantly more sensitive than northern blotting for the detection of small RNAs, and can be performed much more quickly than blotting. The method is quantitative and can be used to compare levels of small RNA expression among different RNA samples (Maroney et al. 2007, 2008).

Annealing Buffer (10×)

\begin{tabular}{lcc} 
Reagent & $\begin{array}{c}\text { Quantity } \\
\text { (for } 1 \mathrm{~mL})\end{array}$ & $\begin{array}{c}\text { Final } \\
\text { concentration }(10 \times)\end{array}$ \\
\hline $\mathrm{KCl}(2 \mathrm{M})$ & $375 \mu \mathrm{L}$ & $750 \mathrm{~mm}$ \\
Tris- $\mathrm{HCl}(1 \mathrm{~m}, \mathrm{pH} 7.5)$ & $200 \mu \mathrm{L}$ & $200 \mathrm{~mm}$ \\
$\mathrm{H}_{2} \mathrm{O}$ & $425 \mu \mathrm{L}$ & -
\end{tabular}

Store indefinitely at $-20^{\circ} \mathrm{C}$. 
T.W. Nilsen

Kinase Buffer (10×)

\begin{tabular}{lcc} 
Reagent & $\begin{array}{c}\text { Quantity } \\
\text { (for } 1 \mathrm{~mL})\end{array}$ & $\begin{array}{c}\text { Final } \\
\text { concentration }(10 \times)\end{array}$ \\
\hline Tris- $\mathrm{HCl}(1 \mathrm{M}, \mathrm{pH} 7.5)$ & $500 \mu \mathrm{L}$ & $500 \mathrm{~mm}$ \\
$\mathrm{MgCl}_{2}(1 \mathrm{M})$ & $100 \mu \mathrm{L}$ & $100 \mathrm{~mm}$ \\
Dithiothreitol (DTT; 1 M) & $50 \mu \mathrm{L}$ & $50 \mathrm{mM}$ \\
$\mathrm{H}_{2} \mathrm{O}$ & $350 \mu \mathrm{L}$ & -
\end{tabular}

Store for up to $6 \mathrm{mo}$ at $-20^{\circ} \mathrm{C}$.

Ligation Buffer (2×)

\begin{tabular}{lcr} 
Reagent & $\begin{array}{c}\text { Quantity } \\
\text { (for } 1 \mathrm{~mL})\end{array}$ & $\begin{array}{c}\text { Final } \\
\text { concentration }(2 \times)\end{array}$ \\
\hline Tris-HCl (1 M, pH 7.6) & $132 \mu \mathrm{L}$ & $132 \mathrm{~mm}$ \\
$\mathrm{MgCl}_{2}(1 \mathrm{~m})$ & $20 \mu \mathrm{L}$ & $20 \mathrm{~mm}$ \\
Dithiothreitol (DTT; 1 M) & $2 \mu \mathrm{L}$ & $2 \mathrm{~mm}$ \\
ATP (100 mM) & $10 \mu \mathrm{L}$ & $1 \mathrm{~mm}$ \\
Polyethylene glycol (PEG; MW 6000) & $750 \mu \mathrm{L}$ & $15 \%(\mathrm{w} / \mathrm{v})$
\end{tabular}

$(20 \%, w / v)$

$\mathrm{H}_{2} \mathrm{O}$

$86 \mu \mathrm{L}$

Store for up to $6 \mathrm{mo}$ at $-20^{\circ} \mathrm{C}$.

Maroney PA, Chamnongpol S, Souret F, Nilsen TW. 2007. A rapid, quantitative assay for direct detection of microRNAs and other small RNAs using splinted ligation. RNA 13: 930-936.

Maroney PA, Chamnongpol S, Souret F, Nilsen TW. 2008. Direct detection of small RNAs using splinted ligation. Nat Prot 3: 279-287.
Rio DC, Ares M Jr, Hannon GJ, Nilsen TW. 2010a. Purification of RNA by SDS solubilization and phenol extraction. Cold Spring Harb Protoc doi: 10.1101/pdb.prot5438.

Rio DC, Ares M Jr, Hannon GJ, Nilsen TW. 2010b. Ethanol precipitation of RNA and the use of carriers. Cold Spring Harb Protoc doi: 10.1101/pdb. prot5440. 


\section{Splinted Ligation Method to Detect Small RNAs}

Timothy W. Nilsen

Cold Spring Harb Protoc; doi: 10.1101/pdb.prot072611

\begin{tabular}{cc}
$\begin{array}{r}\text { Email Alerting } \\
\text { Service }\end{array}$ & Receive free email alerts when new articles cite this article - click here. \\
\hline $\begin{array}{c}\text { Subject } \\
\text { Categories }\end{array}$ & Browse articles on similar topics from Cold Spring Harbor Protocols. \\
& $\begin{array}{c}\text { Molecular Biology, general (1293 articles) } \\
\text { Oligonucleotide Probes (14 articles) } \\
\text { Probes (92 articles) } \\
\text { RNA (317 articles) } \\
\text { RNA, general (269 articles) }\end{array}$ \\
\hline
\end{tabular}

